\title{
Fertigation Strategies for Improving Water Use Efficiency and Limiting Nutrient Loss in Soilless Hippeastrum Production
}

\author{
Youssef Rouphael, Giampaolo Raimondi, Rosanna Caputo, \\ and Stefania De Pascale ${ }^{1}$ \\ Department of Agricultural Sciences, University of Naples Federico II, \\ 80055 Portici, Italy
}

Additional index words. Amaryllis, floricultural industry, hydroponics, nitrate-based strategy, nitrate leaching, recirculating nutrient solution

\begin{abstract}
Implementing nutrient management strategies in soilless culture, which improve water use efficiency (WUE) and limit the loss of eutrophying elements without affecting crop performance, is a priority for the floriculture industry. The aim of the current research was to assess the effect of two nutrient management strategies, based on electrical conductivity (EC) or nitrate-nitrogen $\left(\mathrm{N}-\mathrm{NO}_{3}{ }^{-}\right)$concentration control on plant growth, ornamental quality, plant-water relations, mineral composition, and WUE of greenhouse Hippeastrum grown in semiclosed soilless system. The recirculating nutrient solution was discharged whenever a threshold EC value of $3.0 \mathrm{dS} \cdot \mathrm{m}^{-1}$ was reached (ECbased strategy), or when $\mathrm{N}-\mathrm{NO}_{3}{ }^{-}$concentration decreased below the limit of $1.0 \mathrm{~mol} \cdot \mathrm{m}^{-3}$ (nitrate-based strategy). There were no significant differences in terms of plant growth parameters, stomatal resistance, leaf water relations, and macronutrient composition in plant tissues between the two nutrient management strategies. In the EC- and the nitratebased strategies, the recirculating nutrient solution was flushed 10 and 5 times, respectively. The water loss $\left(W_{\mathrm{L}}\right)$ and the total water use $\left(W_{\text {use }}\right)$ in the EC-based strategy were significantly higher by $261.1 \%$ and $61.5 \%$, respectively, compared with the $\mathrm{N}^{-\mathrm{NO}_{3}}{ }^{-}$-based strategy. In contrast with the EC-based strategy, the adoption of the $\mathrm{N}-\mathrm{NO}_{3}{ }^{-}$-based strategy significantly minimized the nitrate, phosphate, and potassium emissions to the environment. The effective WUE of the system $\left(W U E_{S}\right)$ recorded in the $\mathrm{N}-\mathrm{NO}_{3}{ }^{-}$-based strategy was higher by $55.9 \%$ compared with the one recorded with the EC-based strategy.
\end{abstract}

The greenhouse horticulture industry applies more water, fertilizers, and pesticides per unit of production area than any other agricultural system (Molitor, 1990; Rouphael and Colla, 2009). Minimizing water and fertilizers requirements for greenhouse production represents a major sustainability challenge, since many growers are faced with higher fertilizers costs, decreasing availability of good quality water, as well as restrictions and regulations imposed by several European governments (Incrocci et al., 2014; Rouphael et al., 2008). A promising and effective tool to optimize fertigation and to reduce drainage water runoff from greenhouses is to adopt cultivation systems that capture and reuse the drainage solution such as closed soilless systems (Kläring, 2001; Rouphael and Colla, 2005a, 2005b). Closed-loop systems have been classified as "environmentally friendly" because they significantly improve the WUE as compared with free-drain soilless systems (Massa et al., 2008; Rouphael

Received for publication 30 Jan. 2016. Accepted for publication 31 Mar. 2016.

'Corresponding author. E-mail: depascal@unina. it. et al., 2004). However, in south Mediterranean countries, commercial application of closedloop systems is limited due to high investment cost and major difficulty of the nutrient solution management compared with open-loop systems (Massa et al., 2011; Pardossi et al., 2006; Savvas, 2002). In fact, the accumulation of ballast ions, in particular $\mathrm{Na}^{+}$and $\mathrm{Cl}^{-}$, is frequent in closed soilless systems, especially when low-quality water is used (Rouphael and Colla, 2005a, 2005b; Savvas et al., 2005). This makes necessary the discharge of the nutrient solution resulting in water and nutrient loss (Massa et al., 2011), therefore the term "semiclosed" is used for such cultivation systems (Carmassi et al., 2007).

Several scientists have demonstrated that it is possible to enhance nutrient and WUEs in closed-loop systems by adopting different nutrient management strategies (Massa et al., 2010; Pardossi et al., 2002; Raviv et al., 1998). Current practices for managing nutrients in closed soilless systems are usually based on the daily control of the EC of the nutrient solution. In this strategy, a cropspecific EC threshold is imposed, and the recirculating nutrient solution is discharged whenever the EC reaches the imposed ceiling value. This strategy is widely adopted among vegetables and ornamentals growers due to its practical and cost reasons. However, its main drawback is that EC measurements do not provide information on the concentration of individual ions, and thus do not permit corrections of the nutrient solution composition based on the crop nutrient uptake (Kim et al., 2013). An alternative strategy to the conventional EC-based method could be measuring the concentrations of key nutrients in the recirculating nutrient solution such as $\mathrm{N}-\mathrm{NO}_{3}{ }^{-}$(Massa et al., 2010). In this strategy, the recirculating nutrient solution is flushed whenever the $\mathrm{N}^{-\mathrm{NO}_{3}}{ }^{-}$concentration drops below a threshold value. The nutrient analyses can be performed "ex-situ" in the laboratory by time-consuming methods (e.g., inductively coupled plasma), or "insitu" using expensive ion-specific sensors such as the ion-selective electrode and the ion-selective field-effect transistor sensor, or low-cost quick tests (Maggini et al., 2010; Steidle Neto et al., 2014). The adoption of this nutrient management strategy may give encouraging results in terms of productivity and sustainability by prolonging the use and recirculation of the nutrient solution, thus minimizing nitrate loss from agricultural systems (Massa et al., 2010; Pardossi et al., 2009; Thompson et al., 2013), in accordance with the European Union Nitrate Directive (European Commission, 1991).

Hippeastrum Herb. also known as "Amaryllis" is a genus of $\approx 90$ species and over 600 cultivars and hybrids that belongs to the Amaryllidaceae family native to the Western Cape region of South Africa. Hippeastrum is not only cultivated as potted flowering bulbs but also for the production of cut flowers due to the longevity of its blooms (Phuong et al., 2014). Potted Hippeastrum plants are a significant component of the Italian ornamental industry as a result of the high demand of this product on national and international markets (ISMEA, 2014). Several papers have documented the advantages of specific nutrient management strategies for vegetables greenhouse cultivation (Massa et al., 2010, 2011; Pardossi et al., 2009). However, there is a lack of information about nutrient management strategies that decrease water drainage and nitrate emission without affecting crop performance in floriculture production, in particular in potted Hippeastrum.

The aim of this study was to assess the influence of two nutrient management strategies based on $\mathrm{EC}$ or $\mathrm{N}-\mathrm{NO}_{3}{ }^{-}$control on plant growth, leaf water relations, mineral composition, ornamental quality, WUE, and nutrients loss of Hippeastrum grown in a semiclosed soilless system. These results may be applied in management decisions of the ornamental grower for improving the resource use efficiency.

\section{Materials and Methods}

Plant material, growth conditions, and experimental design. The experiment was conducted from May to Oct. 2008 at the experimental station of the University of Naples Federico II located in Pontecagnano (Salerno), south Italy (lat. $43^{\circ} 31^{\prime} \mathrm{N}$, long. 
$14^{\circ} 58^{\prime} \mathrm{E}$; altitude $60 \mathrm{~m}$ above sea level). Plants were grown in a polyethylene greenhouse under $30 \%$ black shading net. The air temperature inside the greenhouse ranged from 15 to $35^{\circ} \mathrm{C}$.

Bulbs of Hippeastrum (Hippeastrum $\times$ hybridum cv. Red Lion), with a circumference $18 \mathrm{~cm}$ were planted on 7 Apr. into pots containing $5 \mathrm{~L}$ of coco-peat (Botanicoir, London, UK) at Florcom SRL nursery (Ercolano, Italy). At sprouting stage (19 May), the pots were transferred to our greenhouse and placed on eight benches $35-\mathrm{cm}$ wide and $7-\mathrm{m}$ long, with a slope of $1.5 \%$ oriented north-south. The plant density was 6 plants $/ \mathrm{m}^{2}$. A randomized complete-block design with four replicates was used to compare two nutrient management strategies based on the $\mathrm{EC}$ or $\mathrm{N}-\mathrm{NO}_{3}{ }^{-}$concentration in the nutrient solution. Each experimental unit consisted of one bench containing 15 plants.

Nutrient management strategies and nutrient solution supply. The quality of the irrigation water was typical of the area, which is characterized by high bicarbonate concentration $\left(5.4 \mathrm{~mol} \cdot \mathrm{m}^{-3}\right)$. The concentrations of ions in the irrigation water expressed as $\mathrm{mol} \cdot \mathrm{m}^{-3}$ were $0.6 \mathrm{Ca}^{2+}, 0.6 \mathrm{Mg}^{2+}, 0.1 \mathrm{~K}^{+}$, $0.4 \mathrm{Na}^{+}, 0.3 \mathrm{Cl}^{-}$, and $0.1 \mathrm{NO}_{3}^{-}$. Values of $\mathrm{pH}$ and EC were 7.3 and $0.5 \mathrm{dS} \cdot \mathrm{m}^{-1}$ at $25^{\circ} \mathrm{C}$, respectively. The composition of the nutrient solution used in the current experiment was

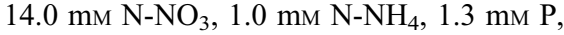
$7.7 \mathrm{~mm} \mathrm{~K}, 3.4 \mathrm{~mm} \mathrm{Ca}, 1.3 \mathrm{~mm} \mathrm{Mg}, 1.5 \mathrm{~mm} \mathrm{~S}$, $25 \mu_{\mathrm{M} \mathrm{Fe}}, 10 \mu_{\mathrm{M} \mathrm{Mn}}, 0.8 \mu \mathrm{M} \mathrm{Cu}, 4 \mu \mathrm{M} \mathrm{Zn}$, $24.5 \mu \mathrm{M} \mathrm{B}$, and $0.5 \mu \mathrm{M}$ Mo.

In all tanks, EC was $2.0 \pm 0.2 \mathrm{dS} \cdot \mathrm{m}^{-1}$ at $25{ }^{\circ} \mathrm{C}$. The $\mathrm{pH}$ of the nutrient solution was always maintained between 5.5 and 6.5 by adding phosphoric acid.

Two different nutrient management strategies for semiclosed systems were compared:

1) EC-based strategy: the mixing tank was refilled with reference nutrient solution (EC of $2.0 \mathrm{dS} \cdot \mathrm{m}^{-1}$ at $25^{\circ} \mathrm{C}$ ) to maintain a relatively constant nutrient concentration. Because of the accumulation of ballast $\left(\mathrm{Na}^{+}\right.$and $\left.\mathrm{Cl}^{-}\right)$and divalent cations $\left(\mathrm{Ca}^{2+}\right.$ and $\left.\mathrm{Mg}^{2+}\right)$, the EC of the recirculating nutrient solution tended to increase. When the cropspecific threshold value of $3.0 \mathrm{dS} \cdot \mathrm{m}^{-1}$ was reached, the nutrient solution was flushed (Dole and Wilkins, 1999).

2) The nitrate-based strategy: the mixing tank was refilled with the fresh nutrient solution as in the EC-based strategy. Nevertheless, when the preset EC value $\left(3.0 \mathrm{dS} \cdot \mathrm{m}^{-1}\right)$ was reached; the tank was replenished with acidified water for 4 to $5 \mathrm{~d}$ to restore the EC to the original target values, till the $\mathrm{N}^{-\mathrm{NO}_{3}}{ }^{-}$ decreased below $1 \mathrm{~mol} \cdot \mathrm{m}^{-3}$, subsequently the nutrient solution was discharged. This $\mathrm{N}^{-\mathrm{NO}_{3}}{ }^{-}$concentration was adopted because $1.42 \mathrm{~mol} \cdot \mathrm{m}^{-3}$ $\mathrm{N}^{-\mathrm{NO}_{3}}{ }^{-}$is the upper limit concentration allowed to be discharged into surface water by the current Italian legislation (Decree 152/2006) and also by the European Nitrate Directive (European Commission, 1991).

In both strategies, the nutrient solution was pumped from an independent mixing tank of $100 \mathrm{~L}$ through a drip irrigation system with one emitter per plant having a flow rate of $3 \mathrm{~L} \cdot \mathrm{h}^{-1}$. Irrigation frequency was regularly adjusted during the growing cycle. Timing varied from 2 to 7 fertigation events per day of $1-3 \mathrm{~min}$.

Data collection, measurements, and analysis. During the growing cycle, whenever the water level in the tank decreased, owing to water lost by crop evapotranspiration $\left(W_{\mathrm{ET}}\right)$, the tank was replenished with acidified water or with reference nutrient solution depending on the nutrient management strategies. The volume of the refill acidified water or reference nutrient solution was determined with a flowmeter.

The $W_{\mathrm{L}}$ was also calculated as the number of discharges times the volume of water discharged in occasion of each flushing. The $W_{\text {use }}$ was computed as the sum of the cumulative crop $W_{\mathrm{ET}}$ and $W_{\mathrm{L}}$. The leaching fraction was also calculated as the $W_{\mathrm{L}}$ divided by the $W_{\text {use }}$.

The nutrient solution $\mathrm{pH}$ and $\mathrm{EC}$ were measured three to four times per week in the recirculating nutrient solution using a $\mathrm{pH}$ meter (HI-9023; Hanna Instruments, Padova, Italy) and a conductivity meter (HI991301; Hanna Instruments), respectively, whereas the nitrate concentration in the solution was determined with a Nitrachek ${ }^{\top M}$ reflectometer (model 404; Quomed, Ltd., England, UK). During each flushing event, nutrient solution samples collected from each tank were directly measured for nitrate $\left(\mathrm{NO}_{3}{ }^{-}\right)$, phosphate $\left(\mathrm{PO}_{4}{ }^{3-}\right)$, and potassium $\left(\mathrm{K}^{+}\right)$concentrations by means of ion chromatography (ICS-3000; Dionex, Sunnyvale, CA). Nitrate, potassium, and phosphate losses were also measured by cumulating the amounts of $\mathrm{NO}_{3}{ }^{-}$, $\mathrm{K}^{+}$, and $\mathrm{PO}_{4}{ }^{3-}$ that were leached during each flushing event from the semiclosed soilless system.

Stomatal resistance was measured three times during the growing cycle $[45,72$, and $99 \mathrm{~d}$ after sprouting (DAS)] on the youngest fully expanded leaves of 16 plants per treatment (four per each replication) with a diffusion porometer (AP-4; Delta-T Devices, Cambridge, UK), between $1200 \mathrm{HR}$ and 1400 HR on a clear sunny day. The water potential components of leaves were also measured psychrometrically on the same date of the stomatal resistance measurements, using a dew-point psychrometer (WP4; Decagon Devices, Pullman, WA). Leaf total water potential $\left(\Psi_{\mathrm{w}}\right)$ was measured at midday. The $\psi_{\mathrm{S}}\left(\Psi_{\pi}\right)$ was measured on frozen/ thawed leaf samples, and the pressure potential $\left(\Psi_{\mathrm{p}}\right)$ was estimated as the difference between $\Psi_{\mathrm{w}}$ and $\Psi_{\pi}$, assuming a matric potential equal to 0 .

At 149 DAS, 10 plants per plot were sampled and separated into leaves, stems, flowers, and bulbs, and their tissues were dried to constant weight in a forced-air oven at $80{ }^{\circ} \mathrm{C}$ for $72 \mathrm{~h}$ for the dry weight determination. Leaf area (LA) was measured with an electronic area meter (LI-3000; LI-COR, Lincoln, NE). The number of harvested stems, leaves, and flowers and the stem length were also recorded. The evapotranspiration water use efficiency $\left(\mathrm{WUE}_{\mathrm{ET}}\right)$ and the effective $\mathrm{WUE}_{\mathrm{S}}$ were calculated as the ratio of plant total dry weight over the cumulative $\mathrm{W}_{\mathrm{ET}}$ or over the $\mathrm{W}_{\text {use }}$, respectively (Baille, 2001; de Pascale et al., 2011).

The dried leaf, stem, bulb, and flower tissues were ground separately in a Wiley mill to pass through a 20 -mesh screen, then samples $(0.5 \mathrm{~g})$ of the dried ground plant tissues were analyzed for the following macronutrients: N, P, and $\mathrm{K}$. Nitrogen concentration was determined after mineralization with sulfuric acid by the Kjeldahl method (Bremner, 1965). Phosphorus and potassium concentration was analyzed after nitricperchloric acid digestion by atomic absorption spectrophotometry according to the method described by Walinga et al. (1995).

Statistical analysis. Analysis of variance of the data was carried out using the SPSS 10 software package for Windows 2001 (www. $\mathrm{ibm} . \mathrm{com} / \mathrm{software} /$ analytics/spss).

\section{Results}

Plant growth and ornamental value. No significant effect of the nutrient management strategy was observed on harvested stem number (average $=5.2$ stems $/ \mathrm{m}^{2}$ ), stem length (average $=52.7 \mathrm{~cm}$ ), leaf number (average $=9.9$ leaves/plant), total leaf area (average $=2889.1 \mathrm{~cm}^{2} /$ plant), and total dry weight (average $=47.0 \mathrm{~g} /$ plant) of potted Hippeastrum plants grown in semiclosed soilless culture (Table 1). However, the number of flowers and flower dry weight were significantly affected by the nutrient management strategy, with the highest values recorded in the nitrate-based strategy (Table 1).

Stomatal resistance and water relations. No significant difference between treatments was observed for the stomatal resistance at $45\left(\right.$ average $\left.=0.88 \mathrm{~s} \cdot \mathrm{cm}^{-1}\right), 72($ average $=$ $\left.0.88 \mathrm{~s} \cdot \mathrm{cm}^{-1}\right)$, and $99\left(\right.$ average $\left.=1.06 \mathrm{~s} \cdot \mathrm{cm}^{-1}\right)$ DAS (Table 2). Similarly, no significant effect of the nutrient management strategy was recorded on water relations in particular on leaf total water potential, $\psi_{\mathrm{S}}$, and pressure potential during the three sampling dates (Table 2).

Plant mineral composition. The macronutrients concentration and distribution in Hippeastrum plants as a function of the nutrient management strategy are displayed in Table 3. Irrespective of the nutrient management strategy, the lowest concentrations of $\mathrm{N}$ and $\mathrm{K}$ were found in the stems, while $\mathrm{P}$ concentration was higher in the leaves in comparison with other plant tissues. The concentration of $\mathrm{N}$ in stems was significantly affected by the nutrient management strategy with higher values recorded for the EC-based strategy than for the nitrate-based one, whereas no significant differences between 
Table 1. Effect of the nutrient management strategy on harvested stem number, stem length, leaf number, total leaf area, flower number, dry weight production, and partitioning of Hippeastrum grown in semiclosed soilless culture.

\begin{tabular}{|c|c|c|c|c|c|c|c|c|c|c|}
\hline \multirow[b]{2}{*}{ Fertigation strategy } & \multirow{2}{*}{$\begin{array}{l}\text { Stem number } \\
\left(\text { no. } / \mathrm{m}^{2}\right)\end{array}$} & \multirow{2}{*}{$\begin{array}{c}\text { Stem } \\
\text { length }(\mathrm{cm})\end{array}$} & \multirow{2}{*}{$\begin{array}{l}\text { Leaf number } \\
\text { (no./plant) }\end{array}$} & \multirow{2}{*}{$\begin{array}{l}\text { Leaf area } \\
\left(\mathrm{cm}^{2} / \text { plant }\right)\end{array}$} & \multirow{2}{*}{$\begin{array}{l}\text { Flower number } \\
\text { (no./plant) }\end{array}$} & \multicolumn{5}{|c|}{ Dry weight (g DW/plant) } \\
\hline & & & & & & $\overline{\text { Leaves }}$ & Stems & Bulbs & Flowers & Total \\
\hline Significance & NS & NS & NS & NS & * & NS & NS & NS & * & NS \\
\hline
\end{tabular}

Ns, *Nonsignificant or significant at $P \leq 0.05$, respectively.

Table 2. Effect of the nutrient management strategy on stomatal resistance $\left[r_{\mathrm{s}}\left(\mathrm{s} \cdot \mathrm{cm}^{-1}\right)\right]$, leaf total water potential $\left[\Psi_{\mathrm{w}}(\mathrm{MPa})\right]$, leaf osmotic potential $\left[\Psi_{\pi}(\mathrm{MPa})\right]$, and leaf turgor potential $\left[\Psi_{\mathrm{P}}(\mathrm{MPa})\right]$ of Hippeastrum grown in semiclosed soilless culture.

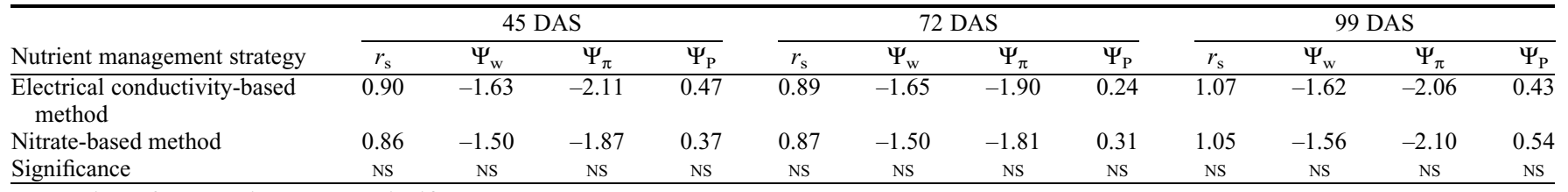

DAS = days after sprouting; NS = nonsignificant.

Table 3. Effect of the nutrient management strategy on the macronutrient composition of leaves, stems, bulbs, and flowers of Hippeastrum grown in semiclosed soilless culture.

\begin{tabular}{|c|c|c|c|c|c|c|c|c|c|c|c|c|}
\hline \multirow[b]{2}{*}{ Nutrient management strategy } & \multicolumn{4}{|c|}{$\mathrm{N}\left(\mathrm{g} \cdot \mathrm{kg}^{-1} \mathrm{DW}\right)$} & \multicolumn{4}{|c|}{$\mathrm{P}\left(\mathrm{g} \cdot \mathrm{kg}^{-1} \mathrm{DW}\right)$} & \multicolumn{4}{|c|}{$\mathrm{K}\left(\mathrm{g} \cdot \mathrm{kg}^{-1} \mathrm{DW}\right)$} \\
\hline & Leaves & Stems & Bulbs & Flowers & Leaves & Stems & Bulbs & Flowers & Leaves & Stems & Bulbs & Flowers \\
\hline
\end{tabular}

DW $=$ dry weight.

Ns, *Nonsignificant or significant at $P \leq 0.05$, respectively.

the treatments were observed in leaves, bulbs, and flowers.

The highest $\mathrm{P}$ and $\mathrm{K}$ concentrations in stems and flowers were recorded in the ECbased strategy, while no significant difference was noted in leaf and bulb tissues (Table 3).

EC, $\mathrm{pH}$, and $\mathrm{N}-\mathrm{NO}_{3}{ }^{-}$concentration in the nutrient solution. There was no significant difference between the two nutrient management strategies in the $\mathrm{pH}$ of the recirculating nutrient solution (data not shown). During the Hippeastrum growing cycle, the $\mathrm{pH}$ of the nutrient solution fluctuated between 5.5 and 6.8 and averaged 6.2 (data not shown). In both nutrient management strategies, the nutrient solution EC oscillated between 1.95 and $3.15 \mathrm{dS} \cdot \mathrm{m}^{-1}$ at $25^{\circ} \mathrm{C}$ (Fig. 1). Moreover,

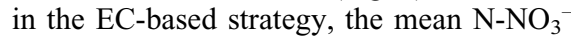
concentration in the recirculating nutrient solution was $12.4 \mathrm{~mol} \cdot \mathrm{m}^{-3}$, while it was considerably lower by $23.4 \%$ in the nitratebased strategy $\left(9.5 \mathrm{~mol} \cdot \mathrm{m}^{-3}\right)$ (Fig. 1). The lower $\mathrm{N}^{-\mathrm{NO}_{3}-}$ concentration in the later treatment can be expected, because when the preset $\mathrm{EC}$ value $\left(3.0 \mathrm{dS} \cdot \mathrm{m}^{-1}\right)$ was reached, the tank was replenished with acidified water for 4 to $5 \mathrm{~d}$ to restore the $\mathrm{EC}$ to the original target value, till the $\mathrm{N}_{-} \mathrm{NO}_{3}{ }^{-}$concentration in the recirculating nutrient solution dropped below $1 \mathrm{~mol} \cdot \mathrm{m}^{-3}$. Consequently, much larger fluctuations in the $\mathrm{N}^{-} \mathrm{NO}_{3}{ }^{-}$concentration were recorded in the nitrate-based compared with the EC-based strategy (Fig. 1).

Water balance and nutrients loss from the semiclosed soilless system. In the current study, no significant effects of the nutrient management strategy were observed on the cumulative $W_{\mathrm{ET}}\left(W_{\mathrm{ET}}\right.$ average $\left.=1532.5 \mathrm{~m}^{3} \cdot \mathrm{ha}^{-1}\right)$, although the $W_{\mathrm{ET}}$ was slightly higher in the EC-based strategy than in the nitrate-based strategy (Table 4). In the EC- and nitrate-based strategies, the recirculating nutrient solution was flushed 10 and 5 times, respectively, taking into consideration the discharge of the residual nutrient solution in the soilless system at the end of the trial. The different frequency of flushing accounted for the large differences between the two nutrient management strategies in $W_{\mathrm{L}}$ and $W_{\text {use. }}$. In fact the $W_{\mathrm{L}}$ and the $W_{\text {use }}$ in the EC-based strategy were significantly higher by $261.1 \%$ and $61.5 \%$, respectively, compared with nitrate-based strategy (Table 4). Finally, in the EC-based strategy the nitrate, phosphate, and potassium losses in the environment were higher by $23,4.5$, and 3.5 times, respectively, compared with the nitratebased strategy (Table 4).

Water use efficiency. The WUE $\mathrm{ET}_{\mathrm{ET}}$ was not significantly affected by the nutrient management strategy with an average value of $1.84 \mathrm{~kg} \cdot \mathrm{m}^{-3}$ (Fig. 2). On the contrary, significant difference between the two nutrient management strategies was observed regarding the effective $\mathrm{WUE}_{\mathrm{S}}$. The results of the current study indicated that $\mathrm{WUE}_{\mathrm{S}}$ recorded in the $\mathrm{N}^{-} \mathrm{NO}_{3}{ }^{-}-$ based strategy $\left(1.59 \mathrm{~kg} \cdot \mathrm{m}^{-3}\right)$ was higher by $55.9 \%$ compared with the one recorded with the EC-based strategy (1.02 $\mathrm{kg} \cdot \mathrm{m}^{-3}$, Fig. 2).

\section{Discussion}

Horticultural crops grown commercially, particularly those cultivated in soilless systems, are focused on increasing productivity through intensification of resource use (i.e., water and fertilizers) to maximize the grower's income. While soilless culture prevents growth being limited by mineral supply (Le Bot et al., 2001), it can lead to luxury nutrient consumption by the crop, resulting in high environmental impact (Savvas, 2002; Savvas et al., 2007). The environmental costs of soilless culture, such as water and soil contamination caused by fertilizers runoff, have led to the beginning of a change in the grower's philosophy away from "purely production-oriented practices" toward those that are more "environmentally sustainable" (Alexanian et al., 2009; Rouphael et al., 2005c; Stefanelli et al., 2010). Hence, implementing management practices such as alternative soilless nutrient management strategies that improve WUE and limit the loss of eutrophying nutrients/ ions (i.e., nitrate and phosphate) without affecting crop performance is a priority for the horticultural in general and the floriculture industry in particular. Our findings demonstrated that, by means of $\mathrm{N}-\mathrm{NO}_{3}{ }^{-}$-based strategy, it was possible to prolong the nutrient solution recirculation in a semiclosed cultivation of Hippeastrum, with the goal of limiting water drainage and minimizing nitrate emission in the environment, with no detrimental effect on plant growth and ornamental value.

The lack of significance between the two nutrient management strategies on plant growth parameters, as well as on biomass production and partitioning could be expected, since the EC in the nutrient solution never 

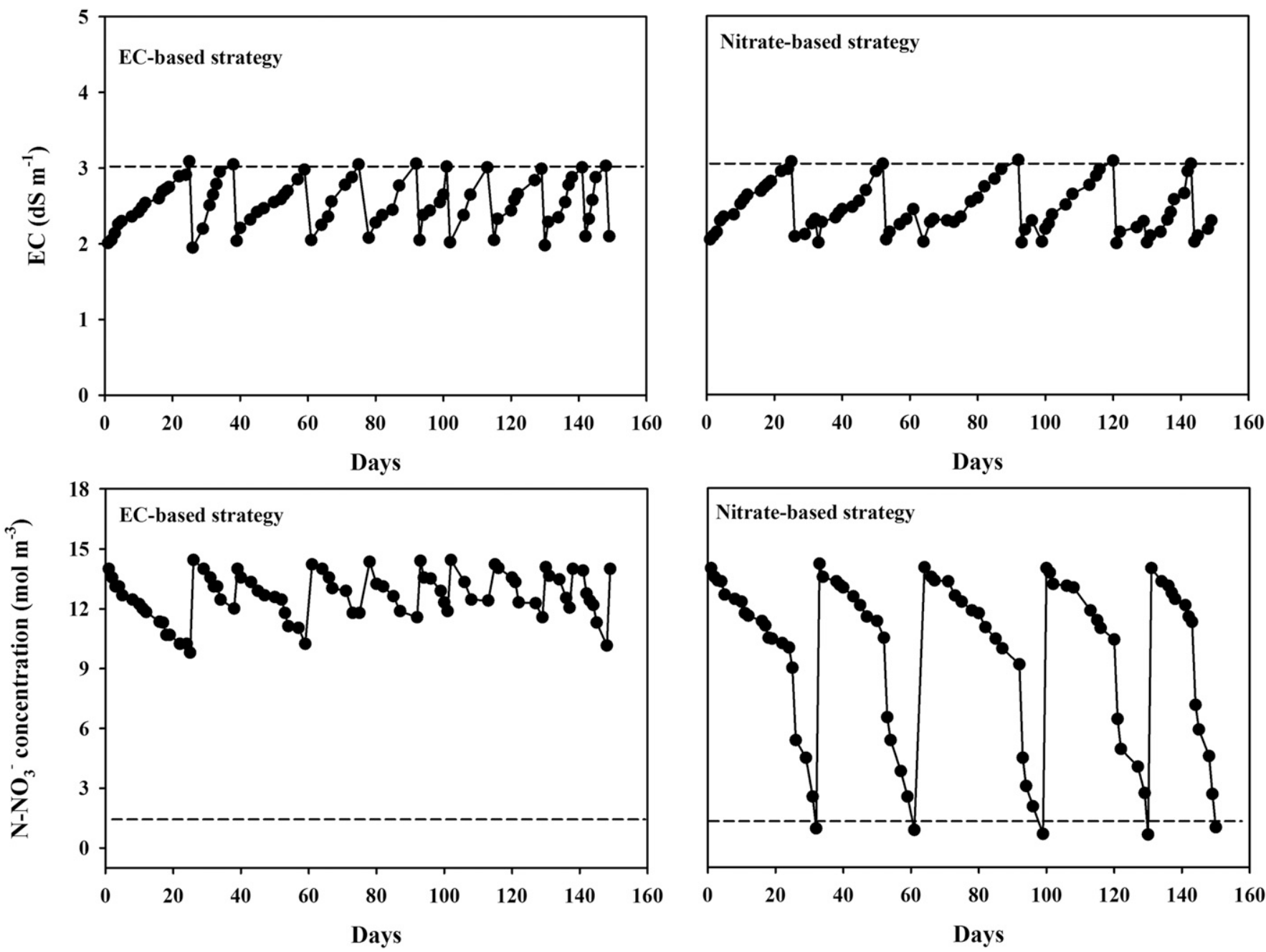

Fig. 1. Changes in the electrical conductivity (EC) and nitrate-nitrogen $\left(\mathrm{N}^{-\mathrm{NO}_{3}}{ }^{-}\right)$concentration of the recirculating nutrient solution as affected by nutrient management strategy of Hippeastrum grown in semiclosed soilless culture. The values are means of four replicates. The dashed line in the upper figures represents the crop-specific EC threshold value $\left(3 \mathrm{dS} \cdot \mathrm{m}^{-1}\right)$, while the dashed line in the lower figures represents the limit imposed to the $\mathrm{N}-\mathrm{NO}_{3}{ }^{-}$concentration of wastewater discharges into the surface water by the Italian legislation $\left(1.42 \mathrm{~mol} \cdot \mathrm{m}^{-3}\right)$.

Table 4. Effect of the nutrient management strategy on the cumulative evapotranspired water $\left(W_{\mathrm{ET}}\right)$, water loss $\left(W_{\mathrm{L}}\right)$, total water use ( $\left.W_{\mathrm{use}}\right)$, number of nutrient solution discharges (flushing events), leaching fraction $\left(\mathrm{LF}=W_{\mathrm{L}} / W_{\text {use }}\right.$ ), and loss of nutrient ions $\left(\mathrm{NO}_{3}{ }^{-}, \mathrm{K}^{+}\right.$, and $\left.\mathrm{PO}_{4}{ }^{3-}\right)$ of Hippeastrum grown in semiclosed soilless culture.

\begin{tabular}{|c|c|c|c|c|c|c|c|c|}
\hline Nutrient management strategy & $W_{\mathrm{ET}}\left(\mathrm{m}^{3} \cdot \mathrm{ha}^{-1}\right)$ & $W_{\mathrm{L}}\left(\mathrm{m}^{3} \cdot \mathrm{ha}^{-1}\right)$ & $W_{\text {use }}\left(\mathrm{m}^{3} \cdot \mathrm{ha}^{-1}\right)$ & Flushing events & LF & $\mathrm{NO}_{3}{ }^{-}\left(\mathrm{kg} \cdot \mathrm{ha}^{-1}\right)$ & $\mathrm{PO}_{4}^{3-}\left(\mathrm{kg} \cdot \mathrm{ha}^{-1}\right)$ & $\overline{\mathrm{K}^{+}\left(\mathrm{kg} \cdot \mathrm{ha}^{-1}\right)}$ \\
\hline Nitrate-based method & $1,417.1$ & 321.2 & $1,738.3$ & 5 & 0.18 & 31.7 & 91.6 & 46.8 \\
\hline Significance & NS & *** & ** & $* * *$ & $* * *$ & *** & *** & ** \\
\hline
\end{tabular}

$\underline{\text { Significance }}{ }^{* *,}, * *$ NS Nonsignificant or significant at $P \leq 0.01$ and 0.001 , respectively.

exceeded the threshold value of $3.0 \cdot \mathrm{dS} \mathrm{m} \mathrm{m}^{-1}$ tolerated by Hippeastrum (Fig. 1). Moreover, it is well known that plants grown under moderate nutrient deficiency are able to store and remobilize the mineral elements as observed in different vegetable crops (Del Amor and Marcelis, 2004; Walker et al., 2001). Indeed, the period of optimal nutrient supply followed by a reduced concentration of the nutrient solution for 4 to 5 d (i.e., nitrate-based strategy, Fig. 1) was much shorter than the 4 weeks of nitrogen deprivation, necessary to decrease plant growth and yield of hydroponically grown tomato (Le Bot et al., 2001). Siddiqi et al. (1998) observed that the interruption of nutrient replenishment for the last $16 \mathrm{~d}$ of the growing cycle did not affect the productivity of greenhouse tomato grown in closed loop system. Similarly, Massa et al. (2010) demonstrated that the interruption of nitrogen supply for few days (3-4) did not affect the marketable yield of greenhouse tomato.

Our results are in line with studies carried out with ornamentals (Cardarelli et al., 2010; Rouphael et al., 2008) in which nutrient solution concentration was reduced by at least $50 \%$ without any detrimental effect on growth and productivity, indicating that the provision of fewer nutrients to Hippeastrum may not have a serious impact on growth and ornamental value. Upregulation of nutrient uptake by plant roots as well as increasing in root biomass may help plants acclimatize to nutritional deficiency (Siddiqi et al., 1998).

The lack of changes between the two nutrient management strategies on agronomical traits may be reflected at physiological level. This was indeed the case, since no significant differences between the treatments were observed for stomatal resistance, leaf total water potential, $\psi_{\mathrm{S}}$, and turgor potential (Table 2), confirming that both the EC- and the $\mathrm{N}_{-} \mathrm{NO}_{3}{ }^{-}$-based strategies did not have considerable effects on potted Hippeastrum growth.

One of the main concerns regarding the use of low concentrated nutrient solutions 


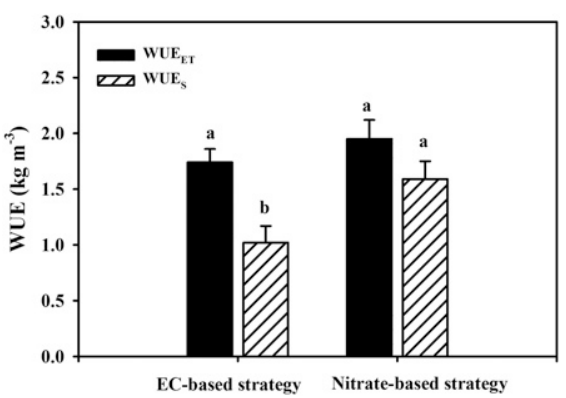

Fig. 2. Effect of the nutrient management strategy on evapotranspiration water use efficiency $\left(\mathrm{WUE}_{\mathrm{ET}}=\right.$ total crop dry weight/cumulative evapotranspired water) and the effective water use efficiency of the system $\left(\mathrm{WUE}_{\mathrm{S}}=\right.$ total crop dry weight/total water use) of Hippeastrum grown in semiclosed soilless culture. The values are means of four replicates. Vertical bars indicate \pm SE of means. Different letters indicate significant differences according to Duncan's test $(P \leq 0.05)$

(i.e., nitrate-based strategy) is the potential of macronutrient deficiency. Based on the nutrient composition of plant tissues, the macronutrient concentrations recorded in both treatments were within the optimum ranges as recommended by Mills and Jones (1996). Therefore, the nitrate-based strategy, implying the nutrient depletion for a few days before discharging the solution, can be adopted in Hippeastrum production without detrimental effect on plant mineral composition, and consequently on growth performance.

Concerning the water balance, the nitratebased strategy was more efficient in terms of $W_{\mathrm{L}}$ and $W_{\text {use }}$ than the EC-based strategy, since it could save $72.3 \%$ and $38.1 \%$ of water, respectively (Table 4). The large differences between the two nutrient management strategies in terms of $W_{\mathrm{L}}$ and $W_{\text {use }}$ were related to the different frequency of flushing: 2 and 5 weeks using the EC- and the nitrate-based strategies, respectively. Moreover, in this study, we found that the relationship between the $W_{\text {use }}$ and the total plant dry weight was affected by the nutrient management strategy. In fact, the effective $\mathrm{WUE}_{\mathrm{S}}$ amounted to 1.59 and $1.02 \mathrm{~kg} \cdot \mathrm{m}^{-3}$ for the nitrate- and the ECbased strategies, respectively (Fig. 2). The higher $\mathrm{WUE}_{\mathrm{S}}$ under the nitrate-based strategy was due to the lower number of flushing events and consequently to the lower volume of $W_{\mathrm{L}}$ from the semiclosed soilless system (Table 4). The concept of WUE is crucial for the floricultural industries, especially that in an era of water scarcity growers have to improve the management practices aiming at saving water and maximizing its productivity (Cardarelli et al., 2010; Rouphael et al., 2005 c, 2008). Finally, in contrast to the ECbased strategy the application of the nitratebased strategy reduced the environmental impact of the production process by minimizing the loss of chemicals from the system, in particular $\mathrm{NO}_{3}{ }^{-}$, which resulted in concentration compatible with the limit allowed to be discharged into surface water by the Italian and the European Nitrate Directive (European Commission, 1991).

\section{Conclusions}

It can be concluded that no significant difference was detected between the two nutrient management strategies in terms of plant growth parameters, leaf water relations, and mineral composition. The results also indicated that by adopting short-term nutrient depletion, it is possible to extend the recirculation of the nutrient solution in semiclosedsoilless cultures of Hippeastrum, aiming to reduce water use, increase WUE, and minimize the loss of eutrophying nutrients (i.e. nitrate and phosphate) in the environment. Finally, the nitrate-based nutrient management strategy should be adopted among floricultural growers due to its positive effect on crop profitability, and since the $\mathrm{N}-\mathrm{NO}_{3}$ concentration in nutrient solution can be easily and routinely measured by means of low cost and quick tests.

\section{Literature Cited}

Alexanian, S., D. Metera, and T. Schuler. 2009 Setting the stage, p. 1-19. In: B.D. McIntyre, H.R. Herren, J. Wakhungu, and R.T. Watson (eds.). Agriculture at a crossroads. International assessment of agricultural knowledge, science and technology for development. Island Press, Washington, DC.

Baille, A. 2001. Water management in soilless cultivation in relation to inside and outside climatic conditions and type of substrate. Ital. Hort. 8:16-22.

Bremner, J.M. 1965. Total nitrogen, p. 1149-1178. In: C.A. Black, D.D. Evans, J.L. White, L.E. Ensminger, and F.E. Clark (eds.). Methods of soil analysis. Part 2. Chemical and microbiological properties. Agronomy Monographs 9. American Society of Agronomy, Soil Science Society of America, Madison, WI.

Cardarelli, M., Y. Rouphael, E. Rea, A. Salerno, and G. Colla. 2010. Nutrient solution concentration and growing season affect growth and quality of potted petunia in a recirculating subirrigation and drip-irrigation system. J. Food Agr. Environ. 8:312-320.

Carmassi, G., I. Incrocci, R. Maggini, F. Malorgio, F. Tognoni, and A. Pardossi. 2007. An aggregated model for water requirements of greenhouse tomato grown in closed rockwool culture with saline water. Agr. Water Mgt. 88:73-82.

De Pascale, S., L. Dalla Costa, S. Vallone, G Barbieri, and A. Maggio. 2011. Increasing water use efficiency in vegetable crop production: From plant to irrigation systems efficiency. HortTechnology 21:301-308.

Del Amor, F.M. and L.F.M. Marcelis. 2004. Regulation of $\mathrm{K}$ uptake, water uptake, and growth of tomato during $\mathrm{K}$ starvation and recovery. Sci. Hort. 100:83-101.

Dole, J.M. and H.F. Wilkins. 1999. Floriculture: principles and species. Prentice Hall, Inc., Upper Saddle River, NJ.

European Commission. 1991. Report from the Commission to the Council and the European Parliament on the implementation of Council Directive 91/676/EEC concerning the protection of waters against pollution caused by nitrates from agriculture sources based on Member State reports for the period 20082011. Off. J. Eur. Commun. L375:1-8.
Incrocci, L., P. Marzialetti, G. Incrocci, A. Di Vita, J. Balendonck, C. Bibbiani, S. Spagnol, and A. Pardossi. 2014. Substrate water status and evapotranspiration irrigation scheduling in heterogeneous container nursery crops. Agr. Water Mgt. 131:30-40.

ISMEA. 2014. Il mercato dei prodotti florovivaistici Rilevazione. 9 Nov. 2015. <http://www. ismea.it>.

Kim, H.J., W.K. Kim, M.Y. Roh, C.I. Kang, J.M. Park, and K.A. Sudduth. 2013. Automated sensing of hydroponic macronutrients using a computer-controlled system with an array of ion-selective electrodes. Comput. Electron. Agr. 93:46-54.

Kläring, H.P. 2001. Strategies to control water and nutrient supplies to greenhouse crops. A review. Agronomie 21:311-321.

Le Bot, J., B. Jeannequin, and R. Fabre. 2001. Growth and nitrogen status of soilless tomato plants following nitrate withdrawal from the nutrient solution. Ann. Bot. 88:361-370.

Maggini, R., G. Carmassi, L. Incrocci, and A. Pardossi. 2010. Evaluation of quick test kits for the determination of nitrate, ammonium and phosphate in soil and in hydroponic nutrient solutions. Agrochimica 54:331-341.

Massa, D., L. Incrocci, R. Maggini, C. Bibbiani, G. Carmassi, F. Malorgio, and A. Pardossi. 2011. Simulation of crop water and mineral relations in greenhouse soilless culture. Environ. Model. Softw. 26:711-722.

Massa, D., L. Incrocci, R. Maggini, G. Carmassi, C.A. Campiotti, and A. Pardossi. 2010. Strategies to decrease water drainage and nitrate emission from soilless cultures of greenhouse tomato. Agr. Water Mgt. 97:971-980.

Massa, D., N.S. Mattson, and H. Lieth. 2008. An empirical model to simulate sodium absorption in roses growing in a hydroponic system. Sci. Hort. 118:228-235.

Mills, H.A. and J.B. Jones. 1996. Plant analysis handbook II: A practical sampling, preparation, analysis, and interpretation guide. MicroMacro Publishing, Athens, GA.

Molitor, H.D. 1990. The European perspective with emphasis on subirrigation and recirculation of water and nutrients. Acta Hort. (272): 165-174.

Pardossi, A., L. Incrocci, D. Massa, G. Carmassi, and R. Maggini. 2009. The influence of fertigation strategies on water and nutrient efficiency of tomato grown in closed soilless culture with saline water. Acta Hort. (807): 445-450.

Pardossi, A., F. Malorgio, L. Incrocci, C.A. Campiotti, and F. Tognoni. 2002. A comparison between two methods to control nutrient delivery to greenhouse melons grown in recirculating nutrient solution culture. Sci. Hort. 92:89-95.

Pardossi, A., F. Malorgio, L. Incrocci, G. Carmassi, R. Maggini, D. Massa, and F. Tognoni. 2006. Simplified models for the water relations of soilless cultures: What they do or suggest for sustainable water use in intensive horticulture. Acta Hort. (718):425-434.

Phuong, P.T.M., S. Isshiki, and I. Miyajima. 2014. Genetic variation of Hippeastrum accessions in Vietnam. J. Fac. Agr. Kyushu Univ. 59:235241.

Raviv, M., A. Krasnovsky, S. Medina, and R. Reuveni. 1998. Assessment of various control strategies for recirculation of greenhouse effluents under semi-arid conditions. J. Hort. Sci. Biotechnol. 73:485-491.

Rouphael, Y., M. Cardarelli, E. Rea, and G. Colla. 2008. The influence of irrigation system and 
nutrient solution concentration on potted geranium production under various conditions of radiation and temperature. Sci. Hort. 118:328-337.

Rouphael, Y. and G. Colla. 2005a. Growth, yield, fruit quality and nutrient uptake of hydroponically cultivated zucchini squash as affected by irrigation systems and growing seasons. Sci. Hort. 105:177-195.

Rouphael, Y. and G. Colla. 2005b. Radiation and water use efficiencies of greenhouse zucchini squash in relation to different climate parameters. Eur. J. Agron. 23:183-194.

Rouphael, Y. and G. Colla. 2009. The influence of drip-irrigation or subirrigation on zucchini squash grown in closed-loop substrate culture with high and low nutrient solution concentrations. HortScience 44:306-311.

Rouphael, Y., G. Colla, A. Battistelli, S. Moscatello, S. Proietti, and E. Rea. 2004. Yield, water requirement, nutrient uptake and fruit quality of zucchini squash grown in soil and soilless culture. J. Hortic. Sci. Biotechnol. 79:423-430.

Rouphael, Y., G. Colla, M. Cardarelli, S. Fanasca, A. Salerno, C.M. Rivera, E. Rea, and F. Karam. 2005c. Water use efficiency of greenhouse summer squash in relation to the method of culture: Soil vs. soilless. Acta Hort. (697):81-86.

Savvas, D. 2002. Nutrient solution recycling, p. 299-343. In: D. Savvas, and H.C. Passam (eds.). Hydroponic productions of vegetables and ornamentals. Embryo Publications, Athens, Greece.

Savvas, D., N. Mantzos, P.E. Barouchas, I.L. Tsirogiannis, C. Olympios, and H.C. Passam. 2007. Modelling salt accumulation by a bean crop grown in a closed hydroponic system in relation to water uptake. Sci. Hort. 111:311318.

Savvas, D., G. Meletiou, S. Margariti, I. Tsirogiannis, and A. Kotsiras. 2005. Modeling the relationship between water uptake by cucumber and $\mathrm{NaCl}$ accumulation in a closed hydroponic system. HortScience 40:802-807.

Siddiqi, M.Y., H.J. Kronzucker, D.T. Britto, and A.D.M. Glass. 1998. Growth of a tomato crop at reduced nutrient concentrations as a strategy to limit eutrophication. J. Plant Nutr. 21:18791895.
Stefanelli, D., I. Goodwin, and R. Jones. 2010. Minimal nitrogen and water use in horticulture: Effects on quality and content of selected nutrients. Food Res. Intl. 43:1833-1843.

Steidle Neto, A.J., J. Zolnier, and D. de Carvalho Lopes. 2014. Development and evaluation of an automated system for fertigation control in soilless tomato production. Comput. Electron. Agr. 103:17-25.

Thompson, R.B., M. Gallardo, J.S. Rodríguez, J.A. Sánchez, and J.J. Magán. 2013. Effect of N uptake concentration on nitrate leaching from tomato grown in free-draining soilless culture under Mediterranean conditions. Sci. Hort. 150:387-398.

Walinga, I.J.J., V.J.G. van der Lee, W. van Vark, and I. Novozamsky. 1995. Plant analysis manual. Kluwer Academic Publishers, Wageningen, The Netherlands.

Walker, R.L., I.G. Burns, and J. Moorby. 2001. Responses of plant growth rate to nitrogen supply: A comparison of relative addition and $\mathrm{N}$ interruption treatments. J. Expt. Bot. 52:309-317. 